\title{
Isolasi Bakteri Pendegradasi Minyak Solar Dari Perairan Teluk Pare-Pare
}

\author{
HASYIMUDDIN $^{1}$, M NATSIR DJIDE ${ }^{2}$, M FARID SAMAWI ${ }^{3}$ \\ ${ }^{1}$ Jurusan Biologi, Fakultas Sains dan Teknologi, UIN Alauddin Makassar \\ Jl. Sultan Alauddin No. 36 Samata, Kab. Gowa, Sulawesi Selatan 92113 \\ email: hasyimuddin@uin-alauddin.ac.id \\ ${ }^{2}$ Fakultas Farmasi, Universitas Hasanuddin \\ Jl. Perintis Kemerdekaan Km 10, Makassar, Sulawesi Selatan 90516 \\ ${ }^{3}$ Fakultas Ilmu Kelautan dan Perikanan, Universitas Hasanuddin \\ Jl. Perintis Kemerdekaan Km 10, Makassar, Sulawesi Selatan 90516
}

\begin{abstract}
This study aims to acquire the diesel oil degrading microbia in Pare-Pare port. This study was conducted at the Laboratory of Microbiology, Department of Biology, Faculty of Science and Technology, UIN Alauddin Makassar. The method is descriptive exploratory study. The data was analyzed by tables and graphs. The results showed that three isolates of bacteria isolated from the Pare-Pare Bay that can degrade diesel oil as Bacillus sp., Psedomonas aeruginosa, and Alkaligenes feacalis. $P$. aeruginosa is the best bacteria in degrading diesel oil.
\end{abstract}

Keywords: bacteria, biodegradation, diesel oil, Pare-Pare Bay

\section{INTISARI}

Penelitian ini bertujuan untuk memperoleh bakteri yang terdapat di Pelabuhan Pare-Pare yang mampu mendegradasi minyak solar. Penelitian dilaksanakan di Laboratorium Mikrobiologi Jurusan Biologi Fakultas Sains dan Teknologi Universitas Islam Negeri Alauddin Makassar. Metode yang digunakan adalah penelitian deskriptif eksploratif. Data yang diperoleh dianalisis secara deskriptif yang dilaporkan dalam bentuk tabel dan grafik. Hasil penelitian menunjukkan bahwa 3 isolat bakteri yang diisolasi dari Teluk Pare-Pare yang dapat mendegradasi minyak solar yaitu Bacillus sp., Psedomonas aeruginosa, dan Alkaligenes feacalis. Bakteri P. aeruginosa merupakan bakteri yang terbaik dalam mendegradasi minyak solar.

Kata kunci: bakteri, biodegradasi, minyak solar, Teluk Pare-Pare

\section{PENDAHULUAN}

Perairan Teluk Pare-Pare merupakan salah satu perairan yang memiliki potensi sumber daya laut yang tinggi. Apabila potensi itu dimanfaatkan semaksimal mungkin akan meningkatkan kesejahteraan masyarakat yang ada di sekitarnya. Namun dengan meningkatnya jumlah penduduk akan menyebabkan peningkatan aktivitas manusia baik di darat maupun di laut, seperti pelabuhan, pemukiman penduduk, pertamina, karantina hewan, kegiatan pasar, industri, dan kegiatan lainnya.

Pengendalian pencemaran dengan mikroba tengah berkembang dan berpotensi di masa mendatang karena teknologinya yang ramah lingkungan (mengurangi dampak penggunaan bahan kimia). Pada lingkungan yang telah lama tercemar serta kolam pengolahan limbah dimungkinkan terdapat bakteri pendegradasi minyak tersebut secara alamiah, bersaing maupun berkonsorsia dengan mikroorganisme lainnya (Suyasa, 2006).

Pencemaran air adalah masuk atau dimasukannya makhluk hidup, zat, energi dan atau komponen lain ke dalam air dan atau berubahnya tatanan air oleh kegiatan manusia atau proses alam sehingga kualitas air turun sampai ketingkat tertentu yang menyebabkan air kurang atau tidak dapat lagi berfungsi sesuai dengan peruntukkannya (Menteri Sekretaris Negara, 2009). Limbah minyak adalah buangan yang berasal dari hasil 
eksplorasi produksi minyak, pemeliharaan fasilitas produksi, fasilitas penyimpanan, pemrosesan, dan tangki penyimpanan minyak pada kapal laut.

Akibat jangka panjang dari pencemaran minyak adalah terutama bagi biota laut yang masih muda. Minyak di dalam laut dapat termakan oleh biota-biota laut. Sebagian senyawa minyak dapat dikeluarkan bersamasama makanan, sedang sebagian lagi dapat terakumulasi dalam senyawa lemak dan protein. Sifat akumulasi ini dapat dipindahkan dari organisme satu ke organisme lain melalui rantai makanan. Jadi, akumulasi minyak di dalam zooplankton dapat berpindah ke ikan pemangsanya. Demikian seterusnya bila ikan tersebut dimakan ikan yang lebih besar, hewan-hewan laut lainnya, dan bahkan manusia (Misran, 2002).

Bakteri merupakan suatu struktur sel yang tidak mempunyai inti sejati (inti yang tidak dikelilingi membran inti), sedangkan komponen genetiknya terdapat di dalam molekul DNA tunggal yang letaknya bebas di dalam sitoplasma (Ali, 2005)

Bakteri merupakan organisme kosmopolit yang dapat kita jumpai di berbagai tempat dengan berbagai kondisi di alam ini. Mulai dari padang pasir yang panas, sampai kutub utara yang beku kita masih dapat menjumpai bakteri. Namun bakteri juga memiliki batasan suhu tertentu dia bisa tetap bertahan hidup.

Bioremediasi adalah proses pembersihan pencemaran tanah dengan menggunakan mikroorganisme. Bioremediasi bertujuan untuk memecah atau mendegradasi zat pencemar menjadi bahan yang kurang beracun atau tidak beracun (karbondioksida dan air).

Secara sederhana proses bioremediasi bagi lingkungan dapat dilakukan dengan mengaktifkan bakteri alami pengurai limbah baik organik maupun anorganik yang akan ditangani. Bakteri-bakteri akan menguraikan limbah tersebut yang telah sedemikian rupa sehingga sesuai dengan kebutuhan hidup bakteri tersebut. Dalam waktu tertentu, bakteri yang telah ditebarkan pada lingkungan yang terkontaminasi tersebut akan menunjukkan bahwa kandungan limbah di lingkungan tersebut mulai berkurang bahkan hilang (Utami, 2010).

\section{METODE}

Teknik pengambilan sampel. Lokasi penelitian adalah perairan Teluk Pare-Pare dengan tiga stasiun pengambilan sampel yaitu Dermaga Nelayan, Pelabuhan Nusantara ParePare dan Pelabuhan Depot Pertamina ParePare

Pada tiap stasiun diambil tiga titik yang ditentukan berdasarkan posisi keterwakilan areal pelabuhan. Sementara pengujian sampel dilaksanakan di Laboratorium Mikrobiologi Jurusan Biologi Fakultas Sains dan Teknologi Universitas Islam Negeri Alauddin Makassar.

Sterilisasi alat. Alat-alat yang terbuat dari gelas disterilkan dengan menggunakan oven pada suhu $180^{\circ} \mathrm{C}$ selama 2 jam. Sebelumnya alat tersebut dibungkus dengan kertas. Alat yang tidak tahan panas/ suhu yang terlalu tinggi disterilkan dengan menggunakan otoklaf pada suhu $121^{\circ} \mathrm{C}$, pada tekanan 2 atm selama 15 menit, sedangkan alat yang terbuat dari aluminium disterilkan dengan menggunakan pijar api.

Pembuatan medium Stone Mineral Salt Solutiont (SMSSe). Semua bahan medium Stone Mineral Salt Solutiont (SMSSe) dilarutkan dalam $1000 \mathrm{ml}$ air suling. Ke dalam medium tersebut ditambahkan minyak solar sebanyak $2 \% \quad(\mathrm{v} / \mathrm{v})$ sebagai sumber karbon, mengatur $\mathrm{pH}$ menjadi 6,5 dengan menggunakan $\mathrm{NaOH} 1 \%$ atau $\mathrm{HCl} 1 \%$. Kemudianmedium dimasukkan ke dalam labu Erlenmeyer dan disterilisasi dengan menggunakan otoklaf pada suhu $121^{\circ} \mathrm{C}$ pada tekanan 2 atm selama 15 menit (Nababan, 2008).

Isolasi bakteri. Isolasi didahului dengan memasukkan sampel air laut yang terkena tumpahan minyak sebanyak 2\% (v/v)ke dalam medium SMSSe kemudian dikocok dengan shaker selama 3 hari dengan kecepatan 120 rpm (Nababan, 2008). Sampel kemudian diisolasi dengan metode pengenceran sampai $10^{-5}$ dengan menggunakan $\mathrm{NaCl}$ fisiologis steril dan dibiakkan dalam lempeng agar medium SMSSe dengan metode cawan tuang lalu diinkubasi selama 48 jam pada suhu 
$35^{\circ} \mathrm{C}$. Setiap koloni yang berbeda dimurnikan kembali pada medium padat yang serupa.

\section{Pengamatan koloni bakteri.}

Pengamatan morfologi dilakukan dengan dua cara yaitu pengamatan Koloni dan pewarnaan Gram. Pengamatan koloni dilakukan secara langsung terhadap isolat untuk melihat penampakan koloni berupa bentuk, tekstur, warna dan elevasi. Sedangkan pengecatan Gram dilakukan untuk melihat bentuk-bentuk sel bakteri dan untuk mengetahui golongan bakteri dari isolat yang dihasilkan. Pengamatan kemudian dilanjutkan dengan uji biokimia untuk menentukan jenis isolat bakteri yang diperoleh.

Uji kemampuan isolat bakteri dalam mendegradasi minyak solar. Masing-masing isolat bakteri yang telah dimurnikan sejumlah $10^{-5} \mathrm{sel} / \mathrm{ml}$, diambil $1 \mathrm{ml}$ lalu ditambahkan ke dalam medium SMSSe cair $(150 \mathrm{ml})$ yang mengandung minyak solar $1 \%(1,5 \mathrm{ml}), 2 \%$ (3 $\mathrm{ml})$ dan 3\% (4,5 ml) secara terpisah. Kultur diinkubasi pada suhu ruang dan digoyang di atas shaker dengan kecepatan $120 \mathrm{rpm}$, lalu dilakukan estimasi kepadatan bakteri pada hari ke-1, 3, 5 dan 7.dengan metode Standart Plate count (SPC) untuk menhitung jumlah koloni bakteri. Perlakuan yang sama juga dilakukan pada kontrol namun perlakuan ini tidak menggunakan isolat bakeri.

Analisis data. Data yang diperoleh dianalisis secara deskriptif yang dilaporkan dalam bentuk tabel dan grafik. Sampel dianalisis dengan menghitung laju pertumbuhan bakteri yang tumbuh pada medium yang diujikan.

Rumus untuk menentukan jumlah koloni bakteri dengan metode Standart Plate Count (SPC) adalah:

$$
\begin{array}{lll}
\text { Faktor pengencer }(\mathbf{F a})= & \begin{array}{l}
\text { Pengenceran } \mathbf{x} \text { Jumlah } \\
\text { sampel }
\end{array} \\
\text { Jumlah koloni per ml }= & \begin{array}{l}
\text { Jumlah koloni per cawan } \\
\mathbf{x} \mathbf{1 / F}
\end{array} \\
\text { Keterangan: } & = & \text { Faktor pengencer } \\
\text { Fa } & =\begin{array}{l}
\text { Tingkat pengenceran yang } \\
\text { dilakukan }
\end{array} \\
\text { Pengenceran } & \text { Jumlah sampel yang diuji } \\
\text { Jumlah sampel } & \text { Jumlah koloni dalam } \\
\text { Jumlah koloni per } \mathrm{ml} & \text { setiap } 1 \mathrm{ml} \text { sampel }
\end{array}
$$

\section{HASIL}

Tabel 1. Morfologi koloni bakteri pendegradasi minyak solar yang diisolasi dari perairan Teluk Pare-Pare

\begin{tabular}{lllllll}
\hline No & \multicolumn{1}{c}{ Isolate } & \multicolumn{1}{c}{ Warna } & \multicolumn{1}{c}{ Bentuk } & \multicolumn{1}{c}{ Tepi } & \multicolumn{1}{c}{ Elevasi } & \multicolumn{1}{c}{ Permukaan } \\
\hline $\mathbf{1}$ & ISL 1 & Kuning & Irregular & Lobate & Raised & Kasar \\
\hline $\mathbf{2}$ & ISL 2 & Putih & Circular & Serrate & Flat & Kasar \\
\hline $\mathbf{3}$ & ISL 3 & Bening & Filamentous & Felamentous & Flat & Kasar \\
\hline
\end{tabular}

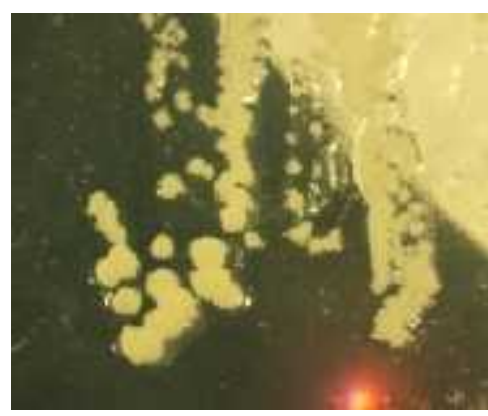

ISL 1

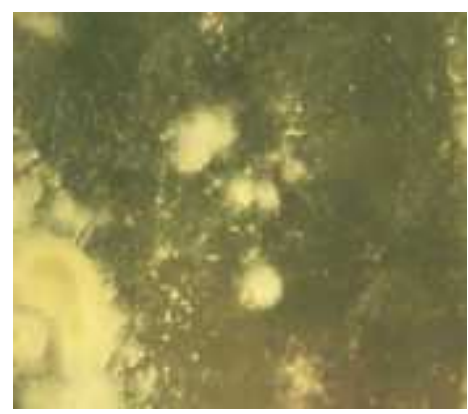

ISL 2

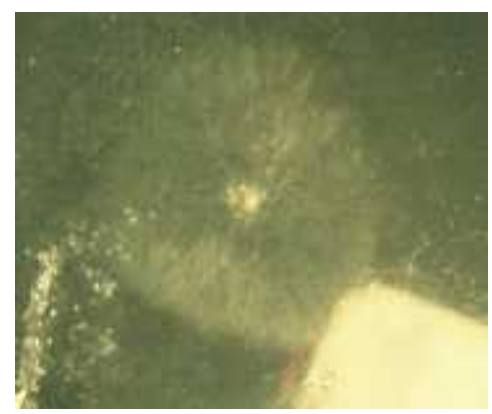

ISL 3

Gambar 1. Isolat bakteri pendegradasi minyak bumi yang diisolasi dari Teluk Pare-Pare 
Tabel 2. Karakteristik sel bakteri setelah pewarnaan Gram

\begin{tabular}{|c|c|c|c|}
\hline Isolat & Bentuk & Gram & Bentuk endospora \\
\hline ISL-1 & Batang & Positif & Elips \\
\hline ISL-2 & Batang & Negatif & Tidak ada \\
\hline ISL-3 & Batang & Negatif & Tidak ada \\
\hline
\end{tabular}

Tabel 3. Uji biokimia isolat pendegradasi minyak solar yang diisolasi dari perairan Teluk Pare-Pare

\begin{tabular}{lcccc} 
& NO & ISL-1 & ISL-2 & ISL-3 \\
\hline MRVP & $-/-$ & $-/-$ & $-/-$ \\
\hline Cimon citrat & - & + & - \\
\hline Urea & - & + & - \\
\hline LIA & + & + & - \\
\hline PAD & - & - & - \\
\hline Malonat & - & - & - \\
\hline Glukosa & + & + & - \\
\hline H2S & - & - & - \\
\hline Laktosa & - & - & - \\
\hline Maltosa & - & - & + \\
\hline Sukrosa & + & - & + \\
\hline Oksidasi Fermentatif & - & + & Alkaligenes feacalis \\
\hline Katalase & + & + & \\
\hline Oksidase & + & Psedomonas & \\
\hline
\end{tabular}

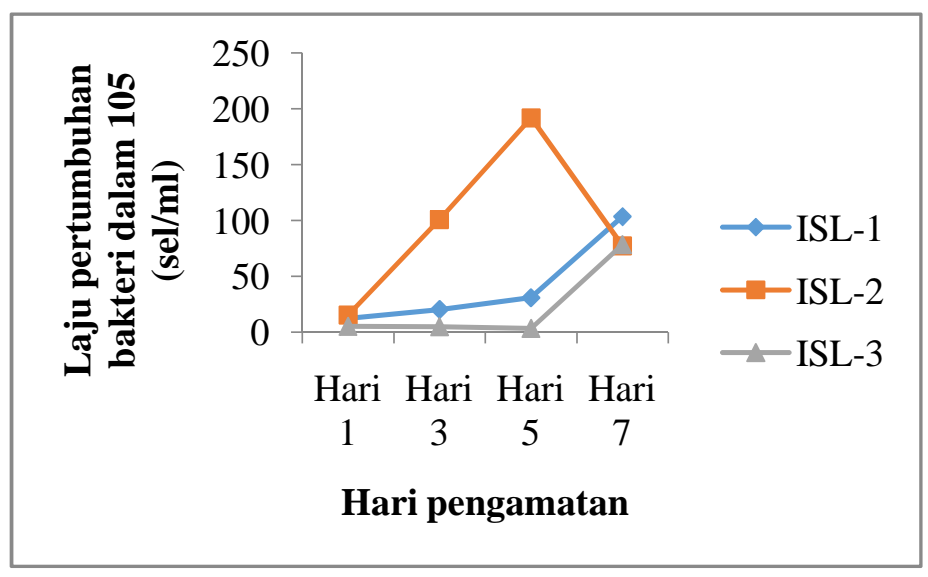

Gambar 2. Laju pertumbuhan isolat bakteri pada konsentrasi minyak $1 \%$ pada pengenceran $10^{-5}$

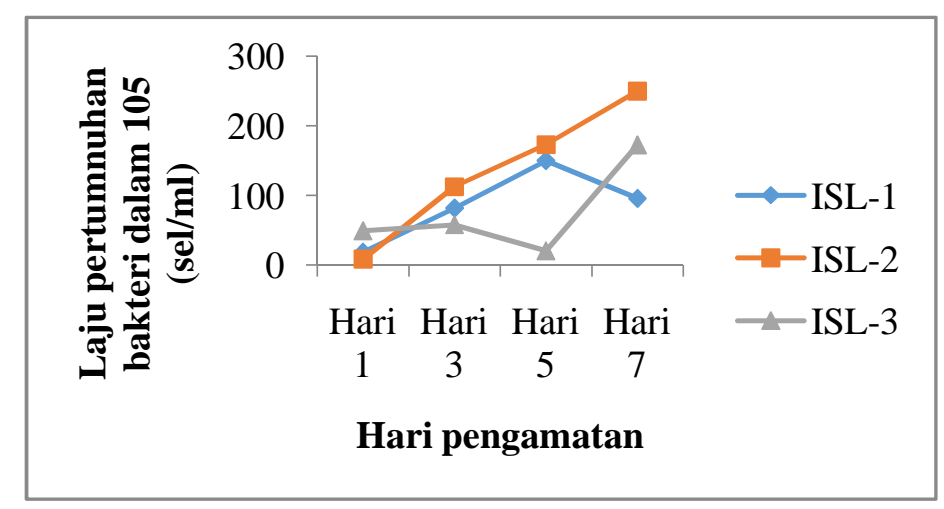

Gambar 3. Laju pertumbuhan isolat bakteri pada konsentrasi minyak $2 \%$ pada pengenceran $10^{-5}$ 


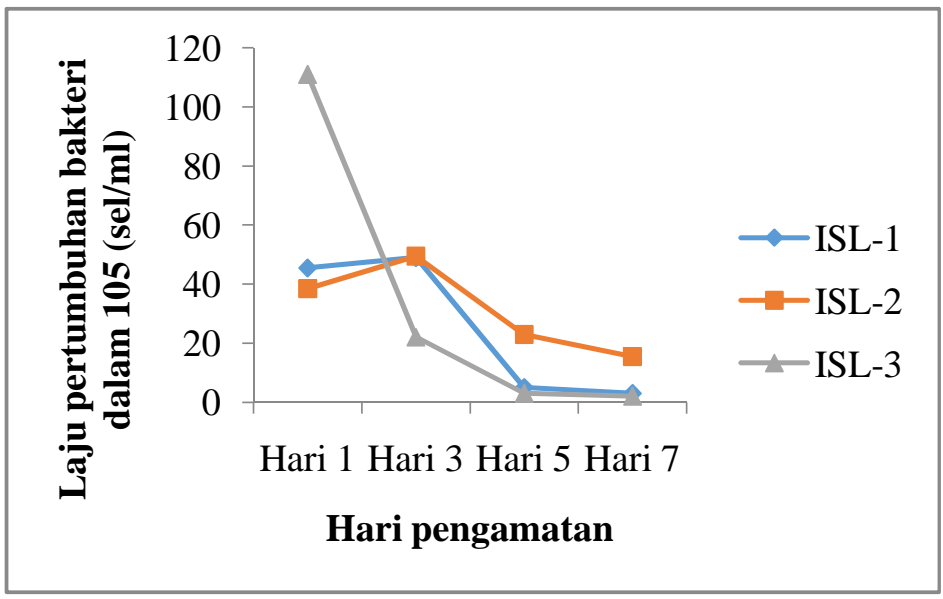

Gambar 4. Laju pertumbuhan isolat bakteri pada konsentrasi minyak $3 \%$ pada pengenceran $10^{-5}$

\section{PEMBAHASAN}

Hasil isolasi yang dilakukan pada tiga lokasi berbeda yakni Pelabuhan Nusantara Pare-Pare, Pelabuhan Depot Pertamina ParePare dan pelabuhan nelayan, diperoleh 3 jenis bakteri pendegradasi minyak solar yang berbeda berdasarkan pengamatan morfologi meliputi pengamatan warna, bentuk, tepi, elevasi koloni dan permukaan sel. Adapun perbedaan bakteri dari segi morfologi disajikan pada Tabel 1.

Berdasarkan Tabel 1 tersebut, koloni bakteri yang tumbuh pada medium minimal setelah diinkubasi selama 48 jam terdapat empat jenis yang diketahui berdasarkan ciriciri morfologi yang dimiliki koloni tersebut. Koloni 1 ditandai dengan bentuk tidak teratur (irregular), pinggiran lobate, permukaannya kasar, bentuk elevasinya agak cembung (raised) dan berwarna kuning. Koloni 2 ditandai dengan bentuk yang juga teratur (circular) dengan pinggiran berbentuk gerigi (serrate) permukaannya rata (flat) dan kasar, berwarna putih, Sedangkan koloni 3 ditandai dengan bentuk seperti filamen-filamen (filamentous), tepi atau pinggirannya pun berbentuk seperti filamen-filamen, permukaan kasar dan elevasi rata (flat) serta warna yang bening.

Isolat ISL 1 didapatkan tumbuh pada setiap sampel yang diuji, isolat ISL 2 diperoleh paling banyak tumbuh di pelabuhan Depot Pertamina Pare-Pare, sedangkan isolat ISL 3 diperoleh dari pelabuhan Nusantara Pare-Pare dan pelabuhan nelayan. Perbedaan jenis bakteri yang tumbuh pada setiap lokasi ini kemungkinan dipengaruhi oleh faktor lingkungan di sekitarnya. Bakteri melakukan adaptasi terhadap lingkungan sehingga mempengaruhi bentuk morfologi serta struktur anatomi dari bakteri tersebut untuk mempertahankan hidupnya.

Pengujian kemudian dilanjutkan dengan pewarnaan gram dan uji biokimia untuk mengetahui jenis dari bakteri yang berhasil diisolasi. Hasil dari uji pewarnaan gram dan uji biokimia disajikan pada Tabel 2 dan 3

Berdasarkan hasil karakteristik, pewarnaan gram dan uji biokimia maka didapatkan isolat ISL-1 adalah Bacillus sp., isolat ISL-2 adalah Psedomonas aeruginosa dan isolat ISL-3 adalah Alkaligenes feacalis.

Uji kemampuan isolat bakteri dalam mendegradasi minyak solar. Sebanyak 3 isolat bakteri pendegradasi minyak solar yang telah diisolasi dan diseleksi selanjutnya dilakukan pengujian kemampuan isolat tersebut dalam mendegradasi minyak solar. Pertumbuhan sel isolat bakteri masing-masing perlakuan dihitung dengan cara SPC dengan menggunakan colony counter dengan pengenceran $10^{-5}$ pada hari ke-1, ke-3, ke-5 dan ke-7.Pertumbuhan isolat bakteri yang ditumbuhkan pada medium minimal cair mengandung minyak solar $1 \%, 2 \%$ dan $3 \%$ bervariasi dari setiap koloni. Hasil pertumbuhan bakteri setelah diuji disajikan dalam Gambar 2, 3 dan 4:

Secara umum pertumbuhan bakteri merupakan hasil penggandaan sel, sehingga 
pertumbuhan bakteri lebih sering dinyatakan sebagai reproduksi sel. Bakteri melakukan penggandaan pembelahan diri secara teratur melalui pertumbuhan eksponensial, yaitu laju pembelahan sel meningkat dengan bertambahnya waktu pertumbuhan (Ali, 2005).

Pada Gambar 2, 3 dan 4 terlihat bahwa pertumbuhan dari setiap isolat yang ditumbuhkan pada medium yang mengandung minyak solar selama tujuh hari memperlihatkan pertumbuhan yang beragam. Isolat 2 mengalami pertumbuhan yang tinggi pada setiap konsentrasi minyak yang diujikan, ini menunjukkan bahwa isolat bakteri tersebut dapat tumbuh pada daerah yang mengandung minyak dan menggunakan minyak tersebut sebagai sumber karbon untuk pertumbuhan.

Pertumbuhan bakteri tertinggi terjadi pada Isolat 2. Angka tertinggi terjadi pada konsetrasi minyak 2\% pada hari ke-7 yakni sebesar $250 \times 10^{5} \mathrm{sel} / \mathrm{mL}$. Pada konsentrasi minyak $1 \%$ isolat 2 mencapai titik satasioner pada hari ke-5 yaitu sebesar $192 \times 10^{5} \mathrm{sel} / \mathrm{mL}$, sedangkan pada konsentrasi $3 \%$ isolat ke-2 mencapai titik maksimum pada hari ke-3 sebesar $49,50 \times 10^{5} \mathrm{sel} / \mathrm{mL}$.

Dari beberapa konsentrasi minyak yang diujikan, konsentrasi minyak $2 \%$ merupakan konsentrasi yang paling baik. Terlihat dari setiap isolat bakteri yang diujikan memperlihatkan pertumbuhan yang baik. Pada konsentrasi nutrien yang amat minim atau terlalu tinggi, maka laju pertumbuhan mikrobia secara proporsional akan menurun. Pada konsentrasi minyak 3\% terlihat laju pertumbuhan yang cenderung menurun. Hal ini karena konsentrasi yang tinggi dapat mempengaruhi kerja enzim yang dihasilkan oleh bakteri sehingga bakteri tidak dapat berkembang dengan baik (Ali, 2005).

Kemampuan bakteri mendegradasikan minyak solar disebabkan karena bakteri menghasilkan enzim yang mampu memecah senyawa organik kompleks menjadi senyawa yang lebih sederhana. Enzim monooksigenase dan enzim dioksigenase yang dihasilkan oleh bakteri mampu membuka ikatan karbon pada cincin aromatik dan menghasilkan alkohol primer. Enzim dioksigenase yang dihasilkan oleh bakteri mendegradasi PAH dan membentuk cis-dihidrodiol. Senyawa ini kemudian didehidrogenasi untuk membentuk dihidroksi-PAH yang merupakan substrat untuk enzim membuka cincin. Melalui pemberian satu molekul oksigen maka enzim monooksigenase juga dapat mendegradasi PAH dan membentuk arene oksida, selanjutnya molekul-molekul ini akan digunakan oleh mikroba sebagai sumber nutrisi untuk pertumbuhan dan energi.

\section{KESIMPULAN}

Diperoleh 3 isolat bakteri yang diisolasi dari Teluk Pare-Pare yang dapat mendegradasi minyak solar yaitu Bacillus sp., Psedomonas aeruginosa, dan Alkaligenes feacalis.

\section{DAFTAR PUSTAKA}

Ali A. 2005. Mikrobiologi Dasar. Makassar: Universitas Negeri Makassar Press.

Misran E. 2002. Aplikasi Teknologi Berbasiskan Membrandalam Bidang Bioteknologi Kelautan: Pengendalian Pencemaran. Medan: Fakultas teknik Program Studi Teknik Kimia Universitas Sumatera Utara.

Mensesneg-RI. PP No 19 Tahun 1999 tentang Pengendalian Pencemaran dan atau Perusakan Laut. Jakarta

Nababan B. 2008. Isolasi dan Uji Potensi Bakteri Pendegradasi Minyak Solar Dari Laut Belawan. Medan: Sekolah Pascasarjana Universitas Sumatera Utara.

Suyasa B. 2006. Isolasi bakteri pendegradasi minyak/lemak dari beberapa sedimen perairan tercemar dan bak penampung limbah. Bali: Jurusan Kimia FMIPA, Universitas Udayana.

Utami AAW. 2010. Pengelolaan Kualitas Lingkungan Bioremediasi Minyak Bumi. Banjar Baru: Fakultas Teknik Universitas Lambung Mangkurat. 